 \\ (1) \\ II

\section{時間周波数標準の発展と応用* \\ Development and Applications of Time and Frequency Standards}

\section{洪 鋒雷 ${ }^{*}$ \\ Feng-Lei Hong}

Key words time standard, frequency standard, optical lattice clock, secondary representations of the second

\section{1. は じめに}

物理の基本単位に対する定義が変わるのは，科学技術の 進歩により, 以前の方法よりも精度よく正確にその量を示 すことができるようになったときである，時間の単位であ る「秒」の定義は現在, セシウム原子のマイクロ波遷移に 基づく原子時計で実現されている. 近年, 原子の光遷移に 基づく次世代原子時計の研究が非常に盛んで，すでにマイ クロ波原子時計の性能を凌ぐ光原子時計が開発されてい る. 時間周波数標準はどのように発展していくのだろう か. ここでは, 秒の定義の変遷を振り返りながら，マイク 口波から光への原子時計の発展について説明した上で, 時 間周波数標準の応用について述べる.

まず図 1 に秒の定義の変遷を示す。1956 年までは, 1 秒は地球の自転から定義され, 1 日（平均太陽日）の 86400 分の 1 と決められていた。潮汐摩擦などによる地球 自転の不整が不確かさの要因であった．1956１967 年の 間では, 1 秒は地球の公転から定義され, 1 太陽年の

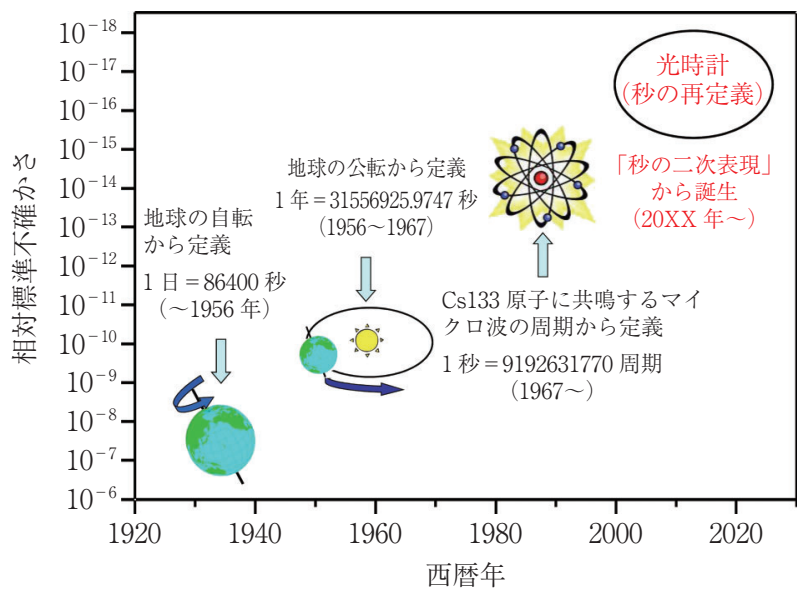

図 1 秒の定義の変遷

*原稿受付 平成 26 年 4 月 24 日

*産業技術総合研究所計測標準研究部門（茨城県つくば市梅園 1-1-1 中央第 3)
31556925.9747 分の 1 とされていた.この定義による秒の不 確かさは約 $2 \times 10^{-9}$ である. 1967 年に, 第 13 回国際度量 衡総会に执いて「秒はセシウム 133 原子の基底状態の 2 つ の超微細準位間の遷移に対応する放射の周期の 9192631770 倍の持続時間である」という新しい定義が採 択された。 セシウム原子時計の不確かさは, 現在では $10^{-16}$ のレベルに到達している.

\section{2. マイクロ波から光の原子時計へ}

時計を構成する 3 つの要素は, 振動子, カウン夕および 表示器である. 原子時計の場合, 振動子は周波数基準（原 子の量子遷移）に同調した電磁波（マイクロ波もしくは 光）である. マイクロ波を利用するセシウム原子時計を使 って時刻を表示するには, カウンタで 9192631770 回の電 磁波振動を測って, 時計の針を 1 秒動かすような仕組みを 使う必要がある。また, 約 $9.2 \mathrm{GHz}$ の周波数を低い周波数 へと分周し, 最終的に $1 \mathrm{~Hz}$ の信号を導き出して, 時計の 針を 1 秒ずつ動かす方法もある.

光の周波数はマイクロ波と比べて 5 桁高いので, 光周波 数標準を用いることで時間をより細かく測定することが可 能となり, 時間分解能が一気に 5 桁上がる. しかし 20 世紀 の終わりまでは, 光周波数標準自身の精度問題に加えて, 光周波数をカウントすることが非常に困難であった．1999 年ごろから, モード同期超短パルスレーザによる「光周波 数コム」を用いたレーザ周波数カウンタの提案がなされ， この分野に扔いて極めて大きな技術革新が起こった11.

光周波数コムの精度が $10^{-17} \sim 10^{-19}$ であること文を考元， 光周波数標準の不確かさがすでに $10^{-18}$ 台でさらに向上中 であること ${ }^{34)}$ を考慮に入れると，いずれ秒の定義はマイ クロ波のセシウム原子時計から光の周波数標準に替わる可 能性が出てくる (図 2). 光周波数標準が秒の定義になる ことは, 光周波数標準に時計の針を 1 秒ずつ動かす仕組み を備える必要があることを意味する，光周波数コムでまず 光周波数をマイクロ波周波数に分周をし, そこから先は従 来のマイクロ波原子時計と同じょうにさらに低い周波数へ と分周し, 最終的に $1 \mathrm{~Hz}$ の信号を導き出す。このよう 


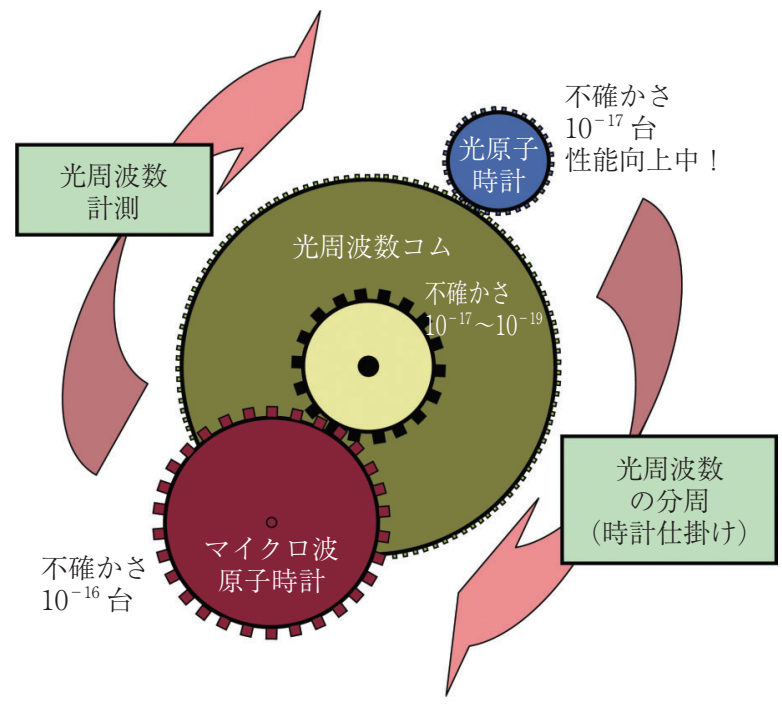

図 2 マイクロ波原子時計と光原子時計をつなぐ光周波数コム

に, 高精度な光周波数標準と光コムの組み合わせで「光原 子時計」が誕生する.

\section{3. 光格子時計の展開}

光原子時計は主に「単一イオン光時計」と「光格子時 計」の 2 つのタプがある (図 3). 単一イオン光時計方 式では, レーザ冷却された単一イオンがトラップポテンシ ヤルの底に置かれ，相互作用時間が長いなどの長所があ る。最新の報告によると, Al イオン時計の不確かさは $8.6 \times 10^{-18}$ に達している ${ }^{3)}$. しかし，イオン時計は単一の 粒子からの弱い信号を使うため, 周波数安定度が上がらな いという欠点がある。

光格子時計は東大工学部香取氏の提案によるもので, レ ーザ光の定在波で作る光格子に閉じ込められる多くの原子 がすべて信号に寄与するので, 周波数安定度がイオン時計 よりもよくなる. また, 光格子を作るレーザ光の強度に依 存した時計遷移の周波数シフト（光シフト）に関しては, 上準位と下準位の光シフトが等しくなる光格子波長（魔法 波長）の存在が見いだされ, 光シフトが時計遷移の周波数 に影響を及ぼさない. 最初に実現された光格子時計は ${ }^{87} \mathrm{Sr}$ によるもので5), その後光周波数計測の結果も更新され ${ }^{6)}$, 今や最も研究されている光原子時計となった. また最近で は, ${ }^{171} \mathrm{Yb}$ を用いた光格子時計も実現され ${ }^{7)}$, 光格子時計 の研究が広がりを見せている.

\section{4. 重カポテンシャルセンサとしての原子時計}

光原子時計の発展の詳細は別の解説 ${ }^{8)}$ に譲るとして, こ こでは光原子時計を含む時間周波数標準の応用について述 ベる。まずは工学的な応用として, 重力ポテンシャルの高 精度センサのテーマを取り上げる。一般相対性理論では, 重力は空間を歪ませ, 時間の進みを遅らせる。地球上で は, 重力場が存在し, 重力のない宇宙空間に比べて時間が ゆっくり進むことになる（重力赤方偏移）。ここでは，相
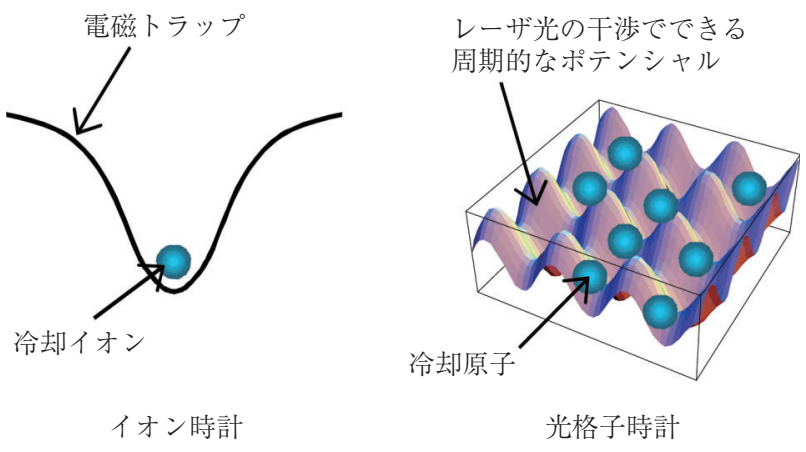

図 3 単一イオン光時計と光格子時計

対性理論で期待される重力場中の原子時計の遅れ（周波数 の低減）を述べ, GPS 衛星, 日本標準時システムおよび 光領域の原子時計による重力赤方偏移の検出を紹介する.

\section{1 重力赤方偏移の理論値}

一般相対性理論では, 重力場中の時計周波数の変化 $(\Delta f)$ は

$$
\frac{\Delta f}{f}=\frac{\Delta U}{c^{2}}
$$

で表される.ここで $f$ は時計の周波数, $U$ は重力ポテンシャ ル, $c$ は光速度である. 球形の地球を仮定すると, 式(1)は

$$
\frac{\Delta f}{f}=\frac{1}{c^{2}}\left(\frac{-G M}{R+\Delta h}-\frac{-G M}{R}\right)
$$

となる，ここで， $G$ は万有引力定数で, $M$ と $R$ はそれぞ れ地球の質量と半径で, $\Delta h$ は高度差である。

\subsection{GPS 衛星時計への相対論効果}

衛星時計の基本周波数は $10.23 \mathrm{MHz}$ である. 衛星軌道 では地球表面と比べて重力ポテンシャルが小さいため, 時 計が早く進み, 時計の周波数が大きくなる. 地球の平均半 径を $R=6370 \mathrm{~km}$, 衛星の平均高度を $\Delta h=20200 \mathrm{~km}$ とし よう。式 (2)に代入して計算すると, $\Delta f$ は $5.29 \times 10^{-10} f$ となり， $0.00541 \mathrm{~Hz}$ だけ周波数が大きくなる．したがっ て, あらかじめ $0.00541 \mathrm{~Hz}$ だけ衛星時計の周波数を小さ くセットしておくと, 地球表面上の観測者が受け取る周波 数がちょうど $10.23 \mathrm{MHz}$ となる. この数值は, 単純化し た導出にも関わらず, 十分に正確である。実際には, 衛星 は衛星軌道で動いているので, 特殊相対論の効果も考慮に 入れる必要がある. 特殊相対論の効果も入れた $\Delta f$ は $0.00446 \mathrm{~Hz}$ となる ${ }^{9)}$.

\section{3 日本標準時システムによる重力赤方偏移の検出}

地表付近では, 式(2)は

$$
\frac{\Delta f}{f} \approx \frac{G M}{c^{2} R^{2}} \Delta h=1.1 \times 10^{-16} \Delta h
$$

となる.すなわち, $1 \mathrm{~m}$ の高さの変化が時計の周波数にお よそ $1 \times 10^{-16}$ の周波数変動を引き起こす.

情報通信研究機構では, 日本標準時システムを整備する ために，セシウム原子時計を標高 700～800 m の福島県お おたかどや山および福岡・佐賀県境のはがね山に運搬し, 高度の変化に伴う重力赤方偏移の検出を試みた ${ }^{10)}$. 観測さ れた值は，理論值の+7.8 $\times 10^{-14}$ のおおたかどや山におい 


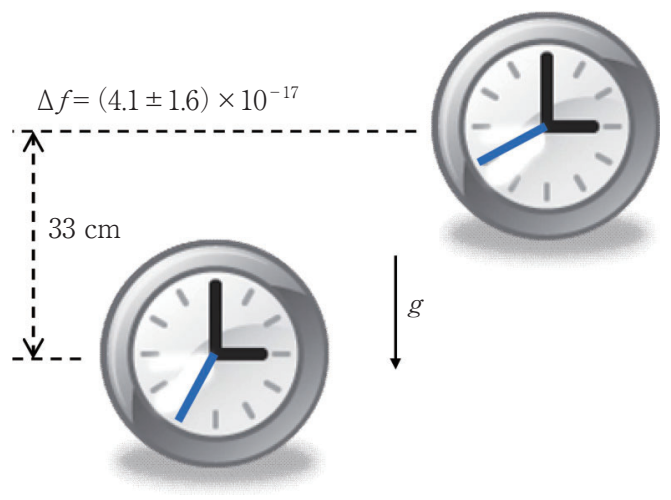

図 $4 \mathrm{Al}$ 単一イオン光時計による重力ポテンシャル変化の検出

て $+7.6 \times 10^{-14}$, 理論值の+9.0 $\times 10^{-14}$ のおおたかどや山に おいて $+12.1 \times 10^{-14}$ である。測定精度が $10^{-14}$ レベルだっ たことを考慮すれば，観測結果は理論值と一致していると いえる。

\section{4 重力センサとしての光時計}

最近では, 米国立標準技術研究所 (NIST) の研究者た ちが光領域の原子時計を使って, 地表付近で $1 \mathrm{~m}$ 以内の 高さの変化による重力ポテンシャルの変動を検出した ${ }^{11}$. 研究者たちは 2 台の $\mathrm{Al}$ イオン時計を用意し, そのうち 1 台の時計を $33 \mathrm{~cm}$ 上げたところ（図 4), その周波数が $(4.1 \pm 1.6) \times 10^{-17}$ 変化したと観測した。 これは上記のセシ ウム原子時計による実験と比べて, 精度が 1000 倍向上し た.さらに, 光時計の短い平均時間の安定度もよいので, 測定時間はセシウム原子時計を利用した実験の数日から数 十分に短縮された。

光時計の性能はまだ向上する余地があるので, 将来的に は $1 \mathrm{~cm}$ レベルの高さ変化に相当する重力ポテンシャルの 変動が検出できる可能性がある。このように感度を高める ことができれば，測地学や水文学，または宇宙における基 礎物理の検証実験にも光時計をさまざまなセンサとして用 いることができる。この性能を利用することで，高性能な 光時計の鉱物探査や地震予知への応用が期待される.

\section{5. 原子時計のその他の応用}

\section{1 物理定数の恒常性の検証}

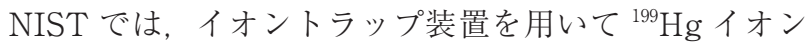
の光領域 $(282 \mathrm{~nm})$ にある $5 \mathrm{~d}^{10} 6 \mathrm{~s}^{2} \mathrm{~S}_{1 / 2} \rightarrow 5 \mathrm{~d}^{9} 6 \mathrm{~s}^{2}{ }^{2} \mathrm{D}_{5 / 2}$ 遷移 の周波数を測定したところ，周波数の基準であるセシウム 原子時計の不確かさで測定精度が制限されていることがわ かった ${ }^{12)}$. イオントラップで得られる $\mathrm{Hg}$ イオン遷移周波 数自身の再現性が 17 桁あるにもかかわらず, 周波数測定 の基準となるセシウム原子時計の精度が 16 桁しかないた め, 測定結果は 16 桁しか得られなかった。これでは, 他 の研究グループが同じ実験を再現しても, 両者の測定結果 が 17 桁で一致することは確認できない.

このようなことを回避する手段の一つとして, NIST で はさらにイオントラップされた ${ }^{27} \mathrm{Al}$ イオンの遷移周波数
を測定した。 ${ }^{27} \mathrm{Al}$ イオンの遷移周波数の測定の再現性が 17 椼あるため, $\mathrm{Hg}$ イオンと $\mathrm{Al}$ イオンの遷移周波数の比 を 17 椼の精度で決定することに成功した ${ }^{13)}$.これはつま り, セシウム原子時計を基準にではなく, Al イオンを基準 に $\mathrm{Hg}$ イオンの遷移周波数を精密に決定したことになる.

では，原子の遷移周波数を 17 椼で決定することはどん な物理的な意味があるのだろうか. 周波数の精密計測は, その標準への応用の他に，物理の基礎的な問題を解決する 上でも役に立つ。宇宙モデルによっては, 初期宇宙での基 礎物理定数は現在と異なり, さらに現在においても物理定 数は変わっていることが示唆されている. 実際, クェーサ 一の分光測定結果を解析することにより, 微細構造定数

( $\alpha$ ）の時間変化が

$$
\frac{\dot{\alpha}}{\alpha}=(6.40 \pm 1.35) \times 10^{-16} / y
$$

と有意にゼロからずれた正の值となったとの報告もあ る ${ }^{14)}$. しかし, 西アフリカのオクロ鉱山の 20 億年前の天 然原子炬の解析では

$$
\frac{\dot{\alpha}}{\alpha}<1 \times 10^{-17} / y
$$

となり，ゼロから有意なズレは得られなかった ${ }^{15)}$.

この問題を解決するもう一つのアプローチが実験室物理 の精密計測である. 原子時計の周波数測定は数年の時間ス ケールで行われるのに対して, 天文や地球物理は億年単位 で変化する現象を扱う。しかし短い測定時間で扱う現象で も，その精度が十分に高ければより有意義な測定結果が得 られるかもしれない. NIST で行われた ${ }^{27} \mathrm{Al}$ イオンと ${ }^{199}$ $\mathrm{Hg}$ イオンの周波数比の測定 ${ }^{13)}$ は

$$
\frac{\dot{\alpha}}{\alpha}=(-1.6 \pm 2.3) \times 10^{-17} / y
$$

の結論を出し, 先に紹介したクェーサーの結果を否定し, オクロ鉱山の結果を支持した。しかも，その精度はすでに オクロ鉱山の分析精度に迫っている.

\section{2 相対性理論を検証する実験}

原子時計は，相対性理論が予測した結果を検証し，時間 と空間の性質について調べる道具として用いることができ る. 特殊相対性理論は「運動する時計は遅れる」と予測し ている。1971年に，物理学者のジョー・ハーフェルとリ チャード・キーティングが原子時計を飛行機に載せ, 世界 一周旅行をさせた。飛行機が元の空港に戻ってきてから， 地上の原子時計との比較実験を行った。 その結果, 飛行機 内の時計の方が, 地上の時計よりも59 ns 遅れていたこと がわかった ${ }^{16)}$ ．実験の不確実な部分が $20 \mathrm{~ns}$ 程度あり，そ の不確実な部分の範囲内で実験結果と相対論の予測が一致 した．原子時計の精度がよくなると，相対性理論を検証す る実験の不確かさが小さくなり, 実験もしやすくなる。例 えば，18 桁の精度の原子時計があれば，相対性理論の検 証実験は人間が歩く速さでできるようになる。

\section{3 秒の再定義一「秒の二次表現」}

光時計に関する研究の飛躍的な発展は, 光時計の測定不 


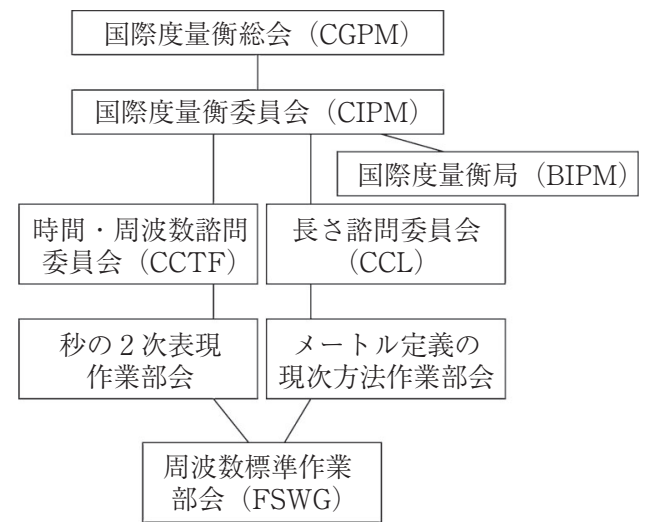

図 5 国際度量衡委員会の組織図

確かさがセシウム原子時計で制限される事態を招いた。国 際度量衡委員会は, このような状況を分析し,「秒の二次 表現」という秒の再定義の候補リストを構築することを決 めた。国際度量衡委員会とその下部組織である時間・周波 数諮問委員会は, 秒の二次表現の選定および管理を「周波 数標準作業部会」に任せている（図 5). 周波数標準作業 部会はさらに, 同じ国際度量衡委員会の下部組織である長 さ諮問委員会から「メートルの定義を実現する波長標準」 の選定および管理が依頼されている。つまり，周波数標準 作業部会の主な仕事は, 光・マイクロ波問わず，ある単一 の周波数リストを作成および管理し, その中から時間・周 波数諮問委員会のために「秒の二次表現」を選定し，長さ 諮問委員会のために「メートルの定義を実現する波長標 準」を選定することである.

周波数標準作業部会の勧告を受けた国際度量衡委員会 は, 2006 年 10 月に, マイクロ波時計の ${ }^{87} \mathrm{Rb}$ および光時 計の ${ }^{88} \mathrm{Sr}+,{ }^{199} \mathrm{Hg}+,{ }^{171} \mathrm{Yb}^{+}$(四重極子遷移), ${ }^{87} \mathrm{Sr}$ が秒 の二次表現として使えることを決めた ${ }^{8)}$. 2009 年には, 秒 の二次表現である ${ }^{87} \mathrm{Sr}$ 光格子時計の新しい研究成果を取 り入れて，その周波数值および不確かさを改訂した。

周波数標準作業部会は，2012 年 9 月 10〜11 日にパリ郊 外の国際度量衡局で会合を開き, 光時計の最新研究成果を 取り入れ，秒の二次表現を含めた単一周波数リストの更新 について議論を行った. 各国から報告された光時計の測定 結果を検討した結果, 新たに ${ }^{171} \mathrm{Yb},{ }^{171} \mathrm{Yb}^{+}$(八重極子遷 移), ${ }^{27} \mathrm{Al}^{+}$の三種類の光時計を秒の二次表現に加えるこ とを決め, 国際度量衡委員会に勧告した。秒の定義に関わ る国際勧告の最新情報は別の解説にまとめた ${ }^{17)}$.

\section{6. おわ に に}

原子時計に関する研究開発は, 今後ますます盛んにな る. 原子時計の高精度化への要求が達成されるにつれ, そ の応用も広がって, 秒の定義も新しく決める必要が出てく る. 光時計は最も精密な量子標準であると同時に, 物理定 数の恒常性を検証する有効なツールや重力ポテンシャルの 高精度センサとして, 基礎科学と実用技術の両面で多くの 研究成果を生み出すことは間違いないであろう.

\section{参 考 文 献}

1) 洪 鋒雷: 光コム一光科学のイノベーション一, 応用物理, 79 (2010) 546.

2) L.-S. Ma, Z. Bi, A. Bartels, L. Robertsson, M. Zucco, R.S. Windeler, G. Wilpers, C. Oates, L. Hollberg and S.A. Diddams: Optical Frequency Synthesis and Comparison with Uncertainty at the $10^{-19}$ Level, Science, 303 (2004) 1843.

3) C.W. Chou, D.B. Hume, J.C.J. Koelemeij, D.J. Wineland and T. Rosenband:Frequency Comparison of Two High-Accuracy Al+ Optical Clocks, Phys. Rev. Lett., 104 (2010) 070802.

4) B.J. Bloom, T.L. Nicholson, J.R. Williams, S.L. Campbell, M. Bishof, X. Zhang, W. Zhang, S.L. Bromley and J. Ye: An Optical Lattice Clock with Accuracy and Stability at the $10^{-18}$ Level, Nature (2014) doi : 10.1038/nature12941.

5) M. Takamoto, F. -L. Hong, R. Higashi and H. Katori : An Optical Lattice Clock, Nature, 435 (2005) 321.

6) F.-L. Hong, M. Musha, M. Takamoto, H. Inaba, S. Yanagimachi, A. Takamizawa, K. Watabe, T. Ikegami, M. Imae, Y. Fujii, M. Amemiya, K. Nakagawa, K. Ueda and H. Katori : Measuring the Frequency of a Sr Optical Lattice Clock Using a $120 \mathrm{~km}$ Coherent Optical Transfer, Opt. Lett., 34 (2009) 692.

7) T. Kohno, M. Yasuda, K. Hosaka, H. Inaba, Y. Nakajima and F.-L. Hong: One-Dimensional Optical Lattice Clock with a Fermionic ${ }^{171}$ Yb Isotope, Appl. Phys. Express, 2 (2009) 072501.

8) 洪 鋒雷：秒の再定義に向けての原子時計の新しい進展一「秒の 二次表現」, 日本物理学会誌, 65 (2010) 80 .

9） B. ホフマンーウェレンホフ，H．リヒテネガー，J。コリンズ： GPS 理論と応用，シュプリンガー・フェアラーク東京，(2005).

10）細川瑞彦：日本標準時システムによる重力赤方偏移の検出, 応 用物理, 73 (2004) 1536 .

11) C.W. Chou, D.B. Hume, T. Rosenband and D.J. Wineland: Optical Clocks and Relativity, Science, 329 (2010) 1630.

12) J.E. Stalnaker, S.A. Diddams, T.M. Fortier, K. Kim, L. Hollberg, J.C. Bergquist, W.M. Itano, M.J. Delany, L. Lorini, W.H. Oskay, T.P. Heavner, S.R. Jefferts, F. Levi, T.E. Parker and J. Shirley : Opticalto-microwave Comparison with Fractional Uncertainty of $10^{-15}$, Appl. Phys. B, 89 (2007) 167.

13) T. Rosenband, D.B. Hume, P.O. Schmidt, C.W. Chou, A. Brusch, L. Lorini, W.H. Oskay, R.E. Drullinger, T.M. Fortier, J.E. Stalnaker, S.A. Diddams, W.C. Swann, N.R. Newbury, W.M. Itano, D.J. Wineland and J.C. Bergquist: Frequency Ratio of $\mathrm{Al}^{+}$and $\mathrm{Hg}^{+}$ Single-Ion Optical Clocks; Metrology at the 17th Decimal Place, Science, 319 (2008) 1808.

14) J.K. Webb, M.T. Murphy, V.V. Flambaum, V.A. Dzuba, J.D. Barrow, C.W. Churchill, J.X. Prochaska and A.M. Wolfe : Further Evidence for Cosmological Evolution of the Fine Structure Constant, Phy. Rev. Lett., 87 (2001) 091301.

15) Y. Fujii, A. Iwamoto, T. Fukahori, T. Ohnuki, M. Nakagawa, H. Hidaka, Y. Oura and P. Möller : The Nuclear Interaction at Oklo 2 Billion Years Ago, Nucl. Phys. B, 573 (2000) 377.

16) J.C. Hafele and R.E. Keating : Around-the-World Atomic Clocks : Observed Relativistic Time Gains, Science, 177 (1972) 168.

17）洪 鋒雷：原子時計の発展と秒の定義に係わる国際勧告, 日本物 理学会誌, 69 (2014) 196.

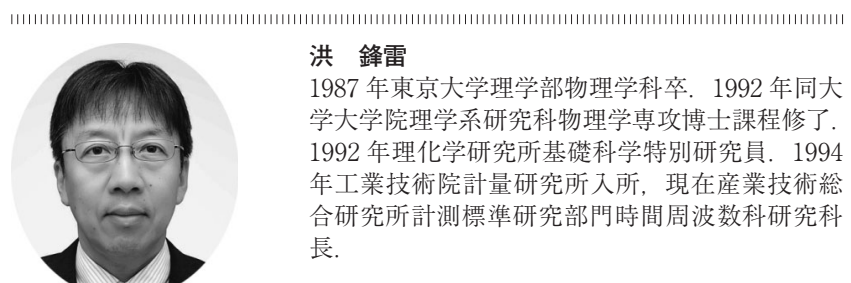

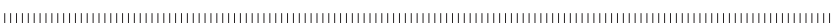

